\title{
Snapshot of microglial physiological functions
}

DOI:

10.1016/j.neuint.2021.104960

Document Version

Accepted author manuscript

Link to publication record in Manchester Research Explorer

\section{Citation for published version (APA):}

Verkhratsky, A., Sun, D., \& Tanaka, J. (2021). Snapshot of microglial physiological functions. Neurochemistry International, 144, 104960. https://doi.org/10.1016/j.neuint.2021.104960

\section{Published in:}

Neurochemistry International

\section{Citing this paper}

Please note that where the full-text provided on Manchester Research Explorer is the Author Accepted Manuscript or Proof version this may differ from the final Published version. If citing, it is advised that you check and use the publisher's definitive version.

\section{General rights}

Copyright and moral rights for the publications made accessible in the Research Explorer are retained by the authors and/or other copyright owners and it is a condition of accessing publications that users recognise and abide by the legal requirements associated with these rights.

\section{Takedown policy}

If you believe that this document breaches copyright please refer to the University of Manchester's Takedown Procedures [http://man.ac.uk/04Y6Bo] or contact uml.scholarlycommunications@manchester.ac.uk providing relevant details, so we can investigate your claim.

\section{OPEN ACCESS}




\title{
Snapshot of Microglial Physiological Functions
}

\author{
Alexei Verkhratsky ${ }^{1,2}$, Dandan $\operatorname{Sun}^{3,4} \&$ Junya Tanaka ${ }^{5^{*}}$ \\ ${ }^{1}$ Faculty of Biology, Medicine and Health, The University of Manchester, Manchester, \\ M13 9PT, UK \\ ${ }^{2}$ Achucarro Centre for Neuroscience, IKERBASQUE, Basque Foundation for Science, \\ 48011 Bilbao, Spain \\ ${ }^{3}$ Department of Neurology and Pittsburgh Institute for Neurodegenerative Disorders, \\ University of Pittsburgh, Pittsburgh, PA 15213, USA \\ ${ }^{4}$ Veterans Affairs Pittsburgh Health Care System, Geriatric Research, Educational and \\ Clinical Center, Pittsburgh, Pennsylvania, 15213, USA \\ ${ }^{5}$ Department of Molecular and Cellular Physiology, Graduate School of Medicine, Ehime \\ University, Ehime 791-0295, Japan.
}

Send all correspondence to:

A. Verkhratsky; email: Alexej.Verkhratsky@manchester.ac.uk

D. Sun; email: sund@upmc.edu

J. Tanaka; email: jtanaka@m.ehime-u.ac.jp 


\begin{abstract}
Microglia as a defensive arm of the nervous system emerged early in evolution. The surveilling microglia with motile and ramified processes are the main phenotype in the healthy CNS; the surveilling microglial patrol neuronal somata, dendrites, dendritic spines and axons. Increasing evidence suggests that microglia play fundamental roles in development, maturation and ageing of the brain, as well as contribute to a variety of physiological brain processes including sleep and circadian rhythm. Physiological state of microglia is tightly regulated by brain microenvironment and controlled by a sophisticated system of receptors and signalling cascades including ionotropic and metabotropic purinoceptors, pattern-recognition receptors, and receptors for chemokines and cytokines. Microglia also utilise ion channels and transporters in regulating ionic homeostasis and various aspects of microglial function. The major ion transporters expressed by microglia include $\mathrm{Na}^{+} / \mathrm{H}^{+}$exchanger 1 and $\mathrm{Na}^{+} / \mathrm{Ca}^{2+}$ exchangers, which are involved in regulation of $\mathrm{pH}_{\mathrm{i}}$ and $\mathrm{Ca}^{2+}$ homeostasis during microglial physiological responses. Microglial cells control development, maturation and plasticity of neuronal ensembles through controlled physiological phagocytosis of synapses or synaptic fragments - processes known as synaptic pruning and trogocytosis. This special issue on "Physiological roles of microglia" is an assembly of papers written by the leading experts in this research field. We start this special issue with this snapshot of microglial physiological functions as a prelude to the indepth discussion of microglia in physiological processes in the nervous system.
\end{abstract}

Key words: Microglia; Neuroprotection; Physiology; Synaptic pruning; Synaptic transmission; Receptors; Transporters 


\section{Microglia: neural cells of myeloid origin}

Microglia as a defensive arm of the nervous system emerged very early in evolution; most notably main features of microglial cells from morphology to major gene clusters are conserved from medicinal leech to Homo sapience (Geirsdottir et al., 2019). Microglia as "garbage collectors" of the central nervous system (CNS) have been discovered and characterised in great detail by Pio del Rio-Hortega, who documented a complex morphological transformations of these cells from ramified phenotype in the healthy brain to amoeboid phagocyte in pathology (Del Rio-Hortega, 1919, 1932; Sierra et al., 2016). In contrast to macroglia of ectodermal origin, microglial cells are alien to the brain: microglial origins are linked to foetal macrophages of the yolk sac that enters the neural tube at early developmental stages prior to the development of blood-brain barrier (Ginhoux et al., 2010; Stremmel et al., 2018; Swinnen et al., 2013). Immigration of macrophages into the neural tube follows a complex pattern, and the yolk sac may not be the only source for microglial precursors (Fehrenbach et al., 2018). Be this as it may, microglial precursors populate embryonic CNS and generate microglial cells dwelling in the adult brain throughout life; the self-renewal and microglial turnover seem to be selfregulated (i.e. not requiring exchange with circulating macrophages) in the healthy nervous system (Askew et al., 2017).

Microglial precursors disseminate throughout the CNS; their migration reaches the peak around birth with post-natal brains being engulfed with "fountains of microglia" (Kershman, 1939). These migrating precursors with amoeboid morphology populate all regions of the CNS and differentiate into surveilling microglia characteristic for the healthy nervous tissue (Kettenmann et al., 2011; Stratoulias et al., 2019; Tay et al., 2019; Wolf et al., 2017). The surveilling phenotype (also known as "resting" or "ramified" microglia" or "surveillant") is highly idiosyncratic: the surveilling microglial cells have small cell body and several thin and long processes with terminal ramifications. These processes are in constant move (Nimmerjahn et al., 2005), scanning nervous tissue and establishing short-living contacts with various parts of neighbouring neurones, with their somata, axons and dendrites (Cserep et al., 2020a; Cserep et al., 2020b; Kettenmann et al., 2013; Tremblay et al., 2013). Microglial processes are endowed with an array of receptors represented by both immunocompetent receptors characteristic for macrophages and by receptors to neurotransmitters and neurohormones characteristic for neural cells (Doens and Fernandez, 2014; Kettenmann et al., 2011; Pocock and Kettenmann, 2007; Szepesi et al., 2018). Co-existence of two sets of receptors makes microglia, arguably, the most "receptive" cells in the CNS. The morphology and physiology of microglia differ fundamentally from peripheral macrophage, which represents a remarkable example of epigenetic metamorphosis of foetal macrophages that adapts them to a highly idiosyncratic environment of the nervous tissue (Garaschuk and Verkhratsky, 2019). Microglial receptors allow these cells to perceive neuronal activity and, at the same time, provide them with sensitivity to danger- and pathogen-associated molecular patterns (DAMPs and PAMPs) associated with pathology (Dasari et al., 2021). Adaptation of macrophages to CNS environment went further making microglial cells indispensable elements of neural networks. Microglial functions are not limited by defence and innate immunity; microglia are actively interacting with all cellular elements of the nervous 
tissue and participate in numerous fundamental physiological functions of the CNS. In particular microglial cells contribute to homeostatic support of neurones, to shaping of neuronal ensembles through synaptic pruning and removal of apoptotic neurones during development, to synaptic transmission through release on various neuroactive molecules and to neuroprotection.

\section{Microglial phenotypes}

Microglial cells account $\sim 5-6 \%$ of all cells in the CNS and they are distributed relatively homogeneously throughout brain regions (Dos Santos et al., 2020); although some variations have been also noted. For example, microglial densities are seemingly higher in the white matter (Mittelbronn et al., 2001; Savchenko et al., 2000). At the same time microglial population is heterogeneous with several distinct physiological phenotypes being described.

Amoeboid microglia of the developing brain are migrating microglial precursors which populate the brain immediately after birth. These cells have large somata with extremely small filopodia and they are capable of amoeboid movement (Haas et al., 1996; Tremblay et al., 2013). Amoeboid microglia settle down and acquire surveilling phenotype by postnatal day $10-15$ in rodents.

The surveilling microglia is the main phenotype in the healthy CNS characterised by a small soma and motile processes. This active surveillance performed by moving processes is brain state-dependent: processes motility is reduced during wakefulness and increased during sleep (Liu et al., 2019). The mobility of microglial processes is a fundamental feature of these cells as it remains active even in conditions of metabolic stress (Szalay et al., 2016). Processes mobility under restricted metabolism can be sustained by utilizing glutamate as an energy substrate (Bernier et al., 2020). Microglial processes establish several distinct types of contacts with neural cells which reflect different patrolling modes.

Microglia-somatic patrolling represents a relatively long-lasting (up to 1 hours) contacts established between microglial process and neuronal soma. These microglia-somatic junctions have specific morphology; they are supported by purinergic signalling and $\mathrm{P}_{2} \mathrm{Y}_{12}$ purinoceptors and are neuroprotective (Cserep et al., 2020b). Microglia-dendritic patrolling is represented by much shorter ( $\sim 5$ minutes) contacts between microglial processes and dendrites and especially dendritic spines. This type of patrolling is linked to synaptic pruning (Kettenmann et al., 2013; Sakai, 2020; Sierra et al., 2010). Microgliaaxonal patrolling reflects intimate contacts established by microglial processes and axonal initial segments; these contact are reported to moderate axonal excitability thus preventing excitotoxicity (Baalman et al., 2015; Kato et al., 2016). Finally, microglial processes converging response represents the protective programme responding to minor lesions to the nervous tissue. Emergence of such lesions is associated with rapid increase in ATP deriving from damaged cells; ATP being an archetypal DAMP (Verkhratsky and Burnstock, 2014) activates microglial $\mathrm{P}_{2} \mathrm{Y}_{12}$ receptors which instigate rapid converging 
movement of microglial processes towards the site in lesion (Davalos et al., 2005; Haynes et al., 2006).

Satellite microglia discovered by Pio del Río-Hortega (Del Rio-Hortega, 1919) has cell bodies which directly contact apical and lateral regions of neuronal somata. In addition satellite extend a process along the axon-initial axonal (Wogram et al., 2016).

The juxtavascular or perivascular microglia (Gehrmann et al., 1995) extend processes toward blood vessels. These processes are terminated with the endfeet, which contribute to formation of glia limitans vascularis (Grossmann et al., 2002; Mondo et al., 2020).

\section{Microglia physiology: receptors}

The physiological state of microglia is tightly regulated by brain microenvironment; in particular a sophisticated system of receptors and signalling cascades controls microglial reactivity, which, if let loose, may cause substantial damage. Microglial state therefore is controlled by two distinct sets of signals - the "On" signals which trigger reactive microgliosis and the "Off" signals that are keeping microglial cells in their surveilling state (Biber et al., 2007; van Rossum and Hanisch, 2004). The On signals are represented by DAMPS and PAMPs, whereas "Off" signals are constitutively present in the healthy nervous tissue, being represented for example by neurotransmitters in physiological concentrations. Conceptually "Off" signals inhibit microglial reactivity; and their disappearance instigates microgliosis. All these signals are operating thorough multiple sets of microglial receptors.

Arguably the most prominent (and certainly the most studied) microglial receptors are represented by purinoceptors; which generally are widespread through all neuroglia (Timmerman et al., 2021; Verkhratsky et al., 2009; Verkhratsky et al., 2012). As alluded before, ATP, released from neurons and glia in physiological context and after damage (Abbracchio et al., 2009; Burnstock et al., 2011) acts as both classical neurotransmitter and archetypal, evolutionary conserved DAMP (Burnstock and Verkhratsky, 2009; Verkhratsky and Burnstock, 2014). As a consequence purinoceptors in pathology are acting as "On" receptors. Microglia express both ionotropic (mainly $\mathrm{P}_{2} \mathrm{X}_{4}$ and $\mathrm{P}_{2} \mathrm{X}_{7}$ ) and metabotropic $\left(\mathrm{P}_{2} \mathrm{Y}_{2}, \mathrm{P}_{2} \mathrm{Y}_{6}, \mathrm{P}_{2} \mathrm{Y}_{12}\right.$, and $\left.\mathrm{P} 2 \mathrm{Y}_{13}\right)$ purinoceptors. In pathological conditions, expression of microglial $\mathrm{P}_{2} \mathrm{X}_{7}$ receptors is up-regulated and activation of $\mathrm{P} 2 \mathrm{X}_{7}$ receptors triggers microgliosis and secretion of pro-inflammatory factors (Kettenmann et al., 2011; Sanz et al., 2009). Furthermore, experimental over-expression of $\mathrm{P}_{2} \mathrm{X}_{7}$ receptors in microglia instigates their reactive transformation even in the absence of any exogenous

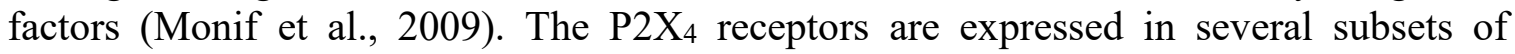
microglia, in particularly in microglia of the spinal cord, where their pathological activation is linked to the neuropathic pain (Tsuda et al., 2003).

Microglial metabotropic purinoceptors are classical G-protein coupled receptors linked to phospholipase $\mathrm{C}$ and $\mathrm{Ins}_{3}$ production which triggers $\mathrm{Ca}^{2+}$ release from the endoplasmic reticulum stores (Kettenmann et al., 2011). Activation of microglial metabotropic purinoceptors is often linked to the activation of secondary store-operated $\mathrm{Ca}^{2+}$ entry 
(SOCE); excessive stimulation of these receptors results in long-lasting stimulation of SOCE, which may substantially modulate microglial reactivity (Toescu et al., 1998). Out of several types of $\mathrm{P} 2 \mathrm{Y}$ receptors expressed by microglia, the $\mathrm{P} 2 \mathrm{Y}_{12}$ purinoceptors are of a specific importance. These receptors are expressed by surveilling microglia in the healthy nervous tissues (Haynes et al., 2006; Sasaki et al., 2003); they are concentrated in microglial processes and regulate various microglial patrolling modes (Cserep et al., 2020a; Lin et al., 2020)

Besides purinoceptors microglial cells express iono- and metabotropic receptors to glutamate (Kaindl et al., 2012; Noda et al., 2000; Yamada et al., 2006), GABA ${ }_{B}$ receptors (Kuhn et al., 2004), $\alpha_{7}$ acetylcholine receptors, $\alpha_{1 \mathrm{~A}}, \alpha_{2 \mathrm{~A}}, \beta_{1}$ and $\beta_{2}$ adrenoceptors (Sugama and Kakinuma, 2020), $\mathrm{D}_{1-4}$ dopamine receptors and 5-HT2 serotonin receptors (Kettenmann et al., 2011). In addition, microglia express numerous receptors to neuromodulators and neurohormones including, for example, receptors to bradykinin, $\mathrm{ET}_{\mathrm{B}}$ endothelin receptors, angiotensin receptors, somatostatin receptors, opioid receptors, and neurotrophin receptors to name but a few (Kettenmann et al., 2011).

From the immune heritage microglia retained expression of pattern-recognition receptors and receptors for chemokines and cytokines. Among pattern-recognition receptors, the Toll-like receptors (or TLRs) are ubiquitously expressed in microglial cells (Aravalli et al., 2007; Bsibsi et al., 2002; Ebert et al., 2007; Gurley et al., 2008; Timmerman et al., 2021). The TLR $1 / 2,6 / 2,4$ and 5 are mainly concentrated in the plasma membrane, whereas TLR3, 7, 8 and 9 are associated within endosomal compartments. The TLR1, TLR2 and TLR6, are activated by bacterial tri- and diacyl lipopeptides, lipoteichoic acid and peptidoglycan, the TLR3 is activated by virus-specific double stranded RNA, TLR4 is the receptor for bacterial cell wall component lipopolysaccharide (LPS), TLR5 is sensitive to bacterial flagellin, TLR7 and TLR8 are activated by viral RNA, whereas TLR 9 detects bacterial and viral unmethylated CpG DNA (Aravalli et al., 2007; Carpentier et al., 2008; Olson and Miller, 2004). As TLR4 expressed by microglia have been implicated in fear memory consolidation in posttraumatic stress disorder (Enomoto and Kato, 2021), TLRs may be involved in physiological process in the brain. Microglial cytokine receptors include TNF- $\alpha$ receptors, interleukin receptors and receptors to interferon $\beta$ and $\gamma$. All these receptors are G-protein coupled and are linked to various signalling cascades such as mitogen-activated protein kinase (MAPK) or phosphatidyl inositol-3 kinase (PI3-K) (Biber et al., 2008).

This remarkable set of receptors of various modalities makes microglia the perfect sentinels of brain environment; the patrolling microglia is capable of perceiving most physiological and pathological signals and mount an appropriate response.

\section{Microglial physiology: solute carrier transporters}

In addition to ionotropic neurotransmitter receptors, SOCE channels, microglia also utilise solute carrier (SLC) ion transporters in regulating ionic homeostasis and activation (Luo et al., 2021). The major ion transporters expressed by microglia include $\mathrm{Na}^{+} / \mathrm{H}^{+}$ exchanger 1 (NHE1), and $\mathrm{Na}^{+} / \mathrm{Ca}^{2+}$ exchangers (NCX). Operation of NHE1 maintains the 
basal intracellular $\mathrm{pH}\left(\mathrm{pH}_{\mathrm{i}}\right)$ of microglia in resting conditions by extrusion of $\mathrm{H}^{+}$in exchange for $\mathrm{Na}^{+}$(Liu et al., 2010). Treatment with LPS or hypoxia stimulation triggers microglial respiratory burst and superoxide production by NADPH oxidase (NOX), which leads to intracellular $\mathrm{H}^{+}$accumulation and acidification (Liu et al., 2010). Activation of NHE1 in microglia is aimed at removing excess $\mathrm{H}^{+}$ions and maintain an optimal alkaline intracellular $\mathrm{pH}\left(\mathrm{pH}_{\mathrm{i}}\right)$ in supporting NOX activity (Lam et al., 2013; Liu et al., 2010; Shi et al., 2013a). The $\mathrm{pH}_{\mathrm{i}}$ homeostasis is also important for microglial chemotaxis and migration (Shi et al., 2013b).

Microglia express all three isoforms of NCX, of which NCX1 is the most abundant (Newell et al., 2007; Parpura et al., 2016). The NCX1 plays a major role in regulation of $\mathrm{Ca}^{2+}$ in microglia, as silencing NCX1 with small interfering RNA (siRNA) completely abolishes $\mathrm{Ca}^{2+}$ signalling in cultured microglia after hypoxia (Boscia et al., 2013; Boscia et al., 2009). Reversal mode of NCX1 ( $\mathrm{NCX}_{\text {rev }}$ ) can be induced by inflammatory factors such as interferon (IFN)- $\gamma$ in cultured microglia, which was mediated by upregulation of protein kinase C (PKC), tyrosine kinase, and MAPK/ERK (Nagano et al., 2004). The $\mathrm{NCX}_{\text {rev-mediated }} \mathrm{Ca}^{2+}$ influx is important for initiation of reactive microgliosis, migration, and phagocytosis after LPS stimulation in early postnatal mice (Sunkaria et al., 2016). However, the NCX1-dependent microglial migration is restricted to the bradykinin-induced chemotaxis, but not ATP-induced migration, as proven in the NCX1 knockout mouse model (Ifuku et al., 2007; Noda et al., 2013). In addition, NCX plays a critical role in microglial phagocytic activity through the $\mathrm{Ca}^{2+}$-dependent activation of the purinergic receptors $\left(\mathrm{P}_{2} \mathrm{Y}_{2}, \mathrm{P}_{2} \mathrm{Y}_{6}\right.$, and $\mathrm{P}_{2} \mathrm{Y}_{12}$ ) during postnatal development (Sunkaria et al., 2016). Thus, $\mathrm{NCX}$ is important for mediating $\mathrm{Ca}^{2+}$ signalling in microglial activation. Microglial SLCs are mainly controlled by transmembrane gradient for $\mathrm{Na}^{+}$ions; operation of SLCs is accompanied with substantial $\mathrm{Na}^{+}$fluxes, and therefore, by analogy with astrocytes (Rose and Verkhratsky, 2016; Verkhratsky et al., 2020), microglial cytosolic $\mathrm{Na}^{+}$signalling can play important role in defining functional responses of these cells.

\section{Microglial physiological functions}

\subsection{Synapse pruning in development}

The surveilling microglia have been shown to engage in maturation of the neural circuits in the developing hippocampus (Paolicelli et al., 2011) or neural pathways in the visual systems (Schafer et al., 2012) by phagocytic elimination of synapses, known as synaptic pruning or synaptic stripping (Kettenmann et al., 2013; Tremblay et al., 2011). This contribution has been revealed by experiments using electron microscopy and/or twophoton in vivo imaging. The frequency of microglia-dendritic/synaptic contacts in in ischemic murine brains depends on continuing activities of the degenerating synapses, favouring elimination of the pre-synapses (Wake et al., 2009). Microglia selectively engulf synapses in the lateral geniculate body in the thalamus that are derived from retinal ganglion cell when the activity of retinal ganglion cells was blocked with tetrodotoxin (Schafer et al., 2012). Microglial elimination of synapses is shown to be activity-dependent in the visual cortex of juvenile mice (Tremblay et al., 2010). Thus, the 
synaptic elimination by microglia depends on the activity of neural circuit. Microglia express the specific marker $\mathrm{CD} 11 \mathrm{~b}$, which is a part of complement $\mathrm{C} 3$ receptor. Microglia may recognise aberrant synapses that are tagged and opsonised with $\mathrm{C} 3$. The C3-tagged synapses are arguably glutamatergic because they express vesicular glutamate transporter 2 (Schafer et al., 2012). Neurone-microglia interactions through synapse pruning may be critical for the functional maturation of glutamatergic presynaptic functions (Basilico et al., 2019). Through elimination of the C3-tagged unnecessary synapses, microglia may play critical roles in the maturation of neural circuits in the developing brains (Konishi and Kiyama, 2020; Miyanishi et al., 2021). Mechanistically synaptic pruning relies of a specific type of en passant physiological (i.e. not associated with reactive microgliosis) phagocytosis which eliminates either whole synapses or their fragments; the latter process known as trogocytosis (Sakai, 2020; Sierra et al., 2010; Weinhard et al., 2018).

\subsection{Synapse pruning in adult brain}

Synaptic pruning by microglia may be at its maximum around at postnatal day 15 in the murine hippocampus (Weinhard et al., 2018). Nonetheless even in the adult healthy brain, microglia engulf and eliminate weak or redundand synapses that are tagged with "eat-mesignal" complement proteins and/or milk fat globule-EGF factor 8 protein (MFG-E8) (Brown and Neher, 2014). Sensory deprivation by removing whiskers causes apoptotic changes in synapses in the primary sensory cortex; these synapses are tagged with complement $\mathrm{Clq}$ that signals to microglial process and instigates synapse elimination (Brown and Neher, 2014). As described above, microglial processes display higher motility during the sleep compare to the awake state (Liu et al., 2019). In accordance with this observation, microglia phagocytose synapses tagged with complement or MFG-E8 during sleep (see Figure 1 and (Choudhury et al., 2020). Microglia eliminate not only weak but also hyperactive glutamatergic synapses that are present in the Parkinson's disease (PD) model brain (Aono et al., 2017). In the PD brain, loss of dopaminergic neurons leads to hyperactivity of glutamatergic neurons in the subthalamic nuclei; as a result, "excitatory transmission" becomes dominant. However, microglia eliminate hyperactive excitatory glutamatergic synapses from the subthalamic nuclei and the excitatory/inhibitory imbalance is somewhat rectified. Thus, microglia may contribute to amelioration of the motor symptoms of PD. This is one example for the role of microglia in the homeostasis in the neurotransmission.

Microglia seem to phagocytose only presynaptic elements (Weinhard et al., 2018). Furthermore, microglia may preferentially eliminate glutamatergic synapses bein less prone to phagocyte GABArgic synapses (Miyanishi et al., 2021). Therefore, impairment of microglial synaptic elimination may cause the imbalance between excitatory and inhibitory synaptic transmission, resulting in CNS pathology. Impaired synaptic elimination by microglia in the mature brain have been implicated in behavioural, psychiatric, and neurologic disorders as well as in disturbances of memory and sleep (Deurveilher et al., 2020; Miyanishi et al., 2021; Nakanishi et al., 2021). For example, autism spectrum disorder may be correlated with reduced synaptic pruning by microglia. Increased synaptic pruning is suspected as one of the pathophysiological causes for 
schizophrenia. Microglial elimination of synapses in the adult hippocampus lead to degradation of memory engrams and enhancement of forgetting of previously learned contextual memory (Wang et al., 2020).

\subsection{Modulation of synaptic activity}

Microglia are also known to interact with ongoing synaptic transmission through secreting several chemical factors (Kettenmann et al., 2011). Ablation of microglia cause functional changes at both pre- and postsynaptic levels; these changes included decrease in expression of vesicular glutamate transporters with subsequent decrease in glutamate release as well as impaired expression of post-synaptic receptors. All these changes were attributed to the decrease in microglial BDNF secretion (Parkhurst et al., 2013). Similarly, microglial secretion of nerve growth factor (NGF) sustains glutamatergic transmission through activation of presynaptic TrkA receptors (Rizzi et al., 2018). Microglia can regulate synaptic transmission through release of exosomes, which contain anandamide; the latter was reported to reduce GABAergic transmission through activation of presynaptic CB-1 receptors (Gabrielli et al., 2015). Genetic elimination of microglial fractalkine CX3CR1 receptor results in aberrant development of glutamatergic transmission (Basilico et al., 2019; Zhan et al., 2014). Stimulation of CX3CR1 receptors with CX3CL1 indices adenosine-dependent signalling that impacts on glutamatergic transmission (Lauro et al., 2008; Ragozzino et al., 2006) acting through presynaptic adenosine receptors (Di Angelantonio et al., 2015; Piccinin et al., 2010). Microglia may also increase presynaptic glutamate release through secretion of IL-1 $\beta$ that acts through postsynaptic NMDA receptors and retrograde messenger signalling (Clark et al., 2015). Microlgial secretion of BDNF regulates inhibitory transmission through activation of neuronal TrkB receptors with subsequent down-regulation of $\mathrm{Cl}^{-}$transporter $\mathrm{KCC} 2$ and aberrant $\mathrm{Cl}^{-}$homoeostasis (Coull et al., 2005). Resulting changes in $\mathrm{Cl}^{-}$transmembrane gradient increases excitability of nociceptive neurones thus contributing to neuropathic pain (Mapplebeck et al., 2016).

\subsection{Neuroprotection}

In addition to protecting appropriate brain functions by synaptic pruning or scavenging of cellular debris, microglia also secrete trophic factors such as cytokine IL-1 $\beta$, IGF1, BDNF, etcetera (Tay et al., 2017) to promote normal brain functions. For example, deletion of the unique subpopulation of microglia in the subventricular zone decreased the survival and migration of newly generated neuroblasts to the olfactory bulb (Ribeiro Xavier et al., 2015). Preventing microglial release of BDNF decreased the formation of cortical dendritic spines during motor learning (Parkhurst et al., 2013). Knockout of microglial CX3CR1 or microglial depletion in mice resulted in cognitive impairment (Parkhurst et al., 2013; Rogers et al., 2011).

\section{Conclusions}

Taken together, microglia are multitasking (migration, phagocytosis of debris, pruning synapses, secretion of cytokines and trophic factors) to maintaining normal brain 
homeostasis and functions. Imbalanced functions or dysregulation of microglial functions contribute to brain pathology development or hindered brain tissue repair in brain diseases. This Special Issue contains reviews of frontier microglial research in the broad spectrum including microglia in physiological brain functions such as sleep (Deurveilher et al., 2020), circadian rhythm regulation (Nakanishi et al., 2021), brain development and brain ageing (Konishi and Kiyama, 2020), as well as in brain pathologies such as neurodevelopmental and psychiatric disorders (Kakinuma, 2020; Miyanishi et al., 2021), stress-induced depressive disorders (Enomoto and Kato, 2021; Kikutani et al., 2020; Sugama and Kakinuma, 2020), acute brain injury (hemorrhagic and ischemic stroke (Dasari et al., 2021; Luo et al., 2021)) and brain tumours (Timmerman et al., 2021). These reviews illustrate the significance of understanding microglial functions and identifying modulators as therapeutic targets for treating brain disorders. 


\section{References}

Abbracchio, M.P., Burnstock, G., Verkhratsky, A., and Zimmermann, H. 2009.

Purinergic signalling in the nervous system: an overview. Trends Neurosci 32, 19-29, doi: $10.1016 /$ j.tins.2008.10.001

Aono, H., Choudhury, M.E., Higaki, H., Miyanishi, K., Kigami, Y., Fujita, K., Akiyama, J.I., Takahashi, H., Yano, H., Kubo, M., Nishikawa, N., Nomoto, M., and Tanaka, J. 2017. Microglia may compensate for dopaminergic neuron loss in experimental Parkinsonism through selective elimination of glutamatergic synapses from the subthalamic nucleus. Glia 65, 1833-1847, doi: 10.1002/glia.23199

Aravalli, R.N., Peterson, P.K., and Lokensgard, J.R. 2007. Toll-like receptors in defense and damage of the central nervous system. J Neuroimmune Pharmacol 2, 297-312, doi: Askew, K., Li, K., Olmos-Alonso, A., Garcia-Moreno, F., Liang, Y., Richardson, P., Tipton, T., Chapman, M.A., Riecken, K., Beccari, S., Sierra, A., Molnar, Z., Cragg, M.S., Garaschuk, O., Perry, V.H., and Gomez-Nicola, D. 2017. Coupled Proliferation and Apoptosis Maintain the Rapid Turnover of Microglia in the Adult Brain. Cell Rep 18, 391-405, doi: 10.1016/j.celrep.2016.12.041

Baalman, K., Marin, M.A., Ho, T.S., Godoy, M., Cherian, L., Robertson, C., and Rasband, M.N. 2015. Axon initial segment-associated microglia. J Neurosci 35, $2283-$ 2292, doi: 10.1523/JNEUROSCI.3751-14.2015

Basilico, B., Pagani, F., Grimaldi, A., Cortese, B., Di Angelantonio, S., Weinhard, L., Gross, C., Limatola, C., Maggi, L., and Ragozzino, D. 2019. Microglia shape presynaptic properties at developing glutamatergic synapses. Glia 67, 53-67, doi: 10.1002/glia.23508

Bernier, L.P., York, E.M., Kamyabi, A., Choi, H.B., Weilinger, N.L., and MacVicar, B.A. 2020. Microglial metabolic flexibility supports immune surveillance of the brain parenchyma. Nat Commun 11, 1559, doi: 10.1038/s41467-020-15267-z Biber, K., Neumann, H., Inoue, K., and Boddeke, H.W. 2007. Neuronal 'On' and 'Off' signals control microglia. Trends Neurosci 30, 596-602, doi:

Biber, K., Vinet, J., and Boddeke, H.W. 2008. Neuron-microglia signaling: chemokines as versatile messengers. J Neuroimmunol 198, 69-74, doi:

Boscia, F., D'Avanzo, C., Pannaccione, A., Secondo, A., Casamassa, A., Formisano, L., Guida, N., Scorziello, A., Di Renzo, G., and Annunziato, L. 2013. New roles of NCX in glial cells: activation of microglia in ischemia and differentiation of oligodendrocytes. Adv Exp Med Biol 961, 307-316, doi: 10.1007/978-1-4614-4756-6_26

Boscia, F., Gala, R., Pannaccione, A., Secondo, A., Scorziello, A., Di Renzo, G., and Annunziato, L. 2009. NCX1 expression and functional activity increase in microglia invading the infarct core. Stroke 40, 3608-3617, doi: 10.1161/STROKEAHA.109.557439 Brown, G.C., and Neher, J.J. 2014. Microglial phagocytosis of live neurons. Nat Rev Neurosci 15, 209-216, doi: 10.1038/nrn3710

Bsibsi, M., Ravid, R., Gveric, D., and van Noort, J.M. 2002. Broad expression of Tolllike receptors in the human central nervous system. J Neuropathol Exp Neurol 61, 10131021, doi:

Burnstock, G., Fredholm, B.B., and Verkhratsky, A. 2011. Adenosine and ATP receptors in the brain. Curr Top Med Chem 11, 973-1011, doi: 10.2174/156802611795347627 
Burnstock, G., and Verkhratsky, A. 2009. Evolutionary origins of the purinergic signalling system. Acta Physiol (Oxf) 195, 415-447, doi: 10.1111/j.1748-

1716.2009.01957.x

Carpentier, P.A., Duncan, D.S., and Miller, S.D. 2008. Glial toll-like receptor signaling in central nervous system infection and autoimmunity. Brain Behav Immun 22, 140-147, doi:

Choudhury, M.E., Miyanishi, K., Takeda, H., Islam, A., Matsuoka, N., Kubo, M., Matsumoto, S., Kunieda, T., Nomoto, M., Yano, H., and Tanaka, J. 2020. Phagocytic elimination of synapses by microglia during sleep. Glia 68, 44-59, doi:

10.1002/glia.23698

Clark, A.K., Gruber-Schoffnegger, D., Drdla-Schutting, R., Gerhold, K.J., Malcangio, M., and Sandkuhler, J. 2015. Selective activation of microglia facilitates synaptic strength. J Neurosci 35, 4552-4570, doi: 10.1523/JNEUROSCI.2061-14.2015 Coull, J.A., Beggs, S., Boudreau, D., Boivin, D., Tsuda, M., Inoue, K., Gravel, C., Salter, M.W., and De Koninck, Y. 2005. BDNF from microglia causes the shift in neuronal anion gradient underlying neuropathic pain. Nature 438, 1017-1021, doi:

10.1038/nature04223

Cserep, C., Posfai, B., and Denes, A. 2020a. Shaping Neuronal Fate: Functional Heterogeneity of Direct Microglia-Neuron Interactions. Neuron, doi:

10.1016/j.neuron.2020.11.007

Cserep, C., Posfai, B., Lenart, N., Fekete, R., Laszlo, Z.I., Lele, Z., Orsolits, B., Molnar, G., Heindl, S., Schwarcz, A.D., Ujvari, K., Kornyei, Z., Toth, K., Szabadits, E., Sperlagh, B., Baranyi, M., Csiba, L., Hortobagyi, T., Magloczky, Z., Martinecz, B., Szabo, G., Erdelyi, F., Szipocs, R., Tamkun, M.M., Gesierich, B., Duering, M., Katona, I., Liesz, A., Tamas, G., and Denes, A. 2020b. Microglia monitor and protect neuronal function through specialized somatic purinergic junctions. Science 367, 528-537, doi:

10.1126/science.aax6752

Dasari, R., Bonsack, F., and Sukumari-Ramesh, S. 2021. Brain injury and repair after intracerebral hemorrhage: The role of microglia and brain-infiltrating macrophages.

Neurochem Int 142, 104923, doi: 10.1016/j.neuint.2020.104923

Davalos, D., Grutzendler, J., Yang, G., Kim, J.V., Zuo, Y., Jung, S., Littman, D.R., Dustin, M.L., and Gan, W.B. 2005. ATP mediates rapid microglial response to local brain injury in vivo. Nat Neurosci 8, 752-758, doi: 10.1038/nn1472

Del Rio-Hortega, P. 1919. El tercer elemento de los centros nerviosos. I. La microglia en estado normal. II. Intervencíon de la microglia en los procesos patológicos. III.

Naturaleza probable de la microglia. Bol. de la Soc. esp. de biol. 9, 69-120, doi:

Del Rio-Hortega, P. (1932). Microglia. In Cytology and cellular pathology of the nervous system. W. Penfield, ed. (New York: Hoeber), pp. 482-534.

Deurveilher, S., Golovin, T., Hall, S., and Semba, K. 2020. Microglia dynamics in sleep/wake states and in response to sleep loss. Neurochem Int, 104944, doi:

10.1016/j.neuint.2020.104944

Di Angelantonio, S., Bertollini, C., Piccinin, S., Rosito, M., Trettel, F., Pagani, F., Limatola, C., and Ragozzino, D. 2015. Basal adenosine modulates the functional properties of AMPA receptors in mouse hippocampal neurons through the activation of A1R A2AR and A3R. Front Cell Neurosci 9, 409, doi: 10.3389/fncel.2015.00409 
Doens, D., and Fernandez, P.L. 2014. Microglia receptors and their implications in the response to amyloid beta for Alzheimer's disease pathogenesis. J Neuroinflammation 11, 48, doi: 10.1186/1742-2094-11-48

Dos Santos, S.E., Medeiros, M., Porfirio, J., Tavares, W., Pessoa, L., Grinberg, L., Leite, R.E.P., Ferretti-Rebustini, R.E.L., Suemoto, C.K., Filho, W.J., Noctor, S.C., Sherwood, C.C., Kaas, J.H., Manger, P.R., and Herculano-Houzel, S. 2020. Similar Microglial Cell Densities across Brain Structures and Mammalian Species: Implications for Brain Tissue Function. J Neurosci 40, 4622-4643, doi: 10.1523/JNEUROSCI.2339-19.2020 Ebert, S., Zeretzke, M., Nau, R., and Michel, U. 2007. Microglial cells and peritoneal macrophages release activin A upon stimulation with Toll-like receptor agonists. Neurosci Lett 413, 241-244, doi:

Enomoto, S., and Kato, T.A. 2021. Involvement of microglia in disturbed fear memory regulation: Possible microglial contribution to the pathophysiology of posttraumatic stress disorder. Neurochem Int 142, 104921, doi: 10.1016/j.neuint.2020.104921 Fehrenbach, M.K., Tjwa, M., Bechmann, I., and Krueger, M. 2018. Decreased microglial numbers in Vav1-Cre(+):dicer knock-out mice suggest a second source of microglia beyond yolk sac macrophages. Ann Anat 218, 190-198, doi: 10.1016/j.anat.2018.03.004 Gabrielli, M., Battista, N., Riganti, L., Prada, I., Antonucci, F., Cantone, L., Matteoli, M., Maccarrone, M., and Verderio, C. 2015. Active endocannabinoids are secreted on extracellular membrane vesicles. EMBO Rep 16, 213-220, doi:

10.15252/embr.201439668

Garaschuk, O., and Verkhratsky, A. 2019. Microglia: The Neural Cells of Nonneural Origin. Methods Mol Biol 2034, 3-11, doi: 10.1007/978-1-4939-9658-2_1 Gehrmann, J., Matsumoto, Y., and Kreutzberg, G.W. 1995. Microglia: intrinsic immuneffector cell of the brain. Brain Res Brain Res Rev 20, 269-287, doi: 10.1016/0165-0173(94)00015-h Geirsdottir, L., David, E., Keren-Shaul, H., Weiner, A., Bohlen, S.C., Neuber, J., Balic, A., Giladi, A., Sheban, F., Dutertre, C.A., Pfeifle, C., Peri, F., Raffo-Romero, A., Vizioli, J., Matiasek, K., Scheiwe, C., Meckel, S., Matz-Rensing, K., van der Meer, F., Thormodsson, F.R., Stadelmann, C., Zilkha, N., Kimchi, T., Ginhoux, F., Ulitsky, I., Erny, D., Amit, I., and Prinz, M. 2019. Cross-Species Single-Cell Analysis Reveals Divergence of the Primate Microglia Program. Cell 179, 1609-1622 e1616, doi: 10.1016/j.cell.2019.11.010 Ginhoux, F., Greter, M., Leboeuf, M., Nandi, S., See, P., Gokhan, S., Mehler, M.F., Conway, S.J., Ng, L.G., Stanley, E.R., Samokhvalov, I.M., and Merad, M. 2010. Fate mapping analysis reveals that adult microglia derive from primitive macrophages. Science 330, 841-845, doi: 10.1126/science.1194637 Grossmann, R., Stence, N., Carr, J., Fuller, L., Waite, M., and Dailey, M.E. 2002. Juxtavascular microglia migrate along brain microvessels following activation during early postnatal development. Glia 37, 229-240, doi:

Gurley, C., Nichols, J., Liu, S., Phulwani, N.K., Esen, N., and Kielian, T. 2008. Microglia and Astrocyte Activation by Toll-Like Receptor Ligands: Modulation by PPAR-gamma Agonists. PPAR Res 2008, 453120, doi:

Haas, S., Brockhaus, J., Verkhratsky, A., and Kettenmann, H. 1996. ATP-induced membrane currents in ameboid microglia acutely isolated from mouse brain slices. Neuroscience 75, 257-261, doi: 10.1016/0306-4522(96)00270-9 
Haynes, S.E., Hollopeter, G., Yang, G., Kurpius, D., Dailey, M.E., Gan, W.B., and Julius, D. 2006. The $\mathrm{P}_{2} \mathrm{Y}_{12}$ receptor regulates microglial activation by extracellular nucleotides. Nat Neurosci 9, 1512-1519, doi: 10.1038/nn1805

Ifuku, M., Farber, K., Okuno, Y., Yamakawa, Y., Miyamoto, T., Nolte, C., Merrino, V.F., Kita, S., Iwamoto, T., Komuro, I., Wang, B., Cheung, G., Ishikawa, E., Ooboshi, H., Bader, M., Wada, K., Kettenmann, H., and Noda, M. 2007. Bradykinin-induced microglial migration mediated by $\mathrm{B} 1$-bradykinin receptors depends on $\mathrm{Ca} 2+$ influx via reverse-mode activity of the $\mathrm{Na}+\mathrm{Ca} 2+$ exchanger. J Neurosci 27, 13065-13073, doi: 10.1523/JNEUROSCI.3467-07.2007

Kaindl, A.M., Degos, V., Peineau, S., Gouadon, E., Chhor, V., Loron, G., Le Charpentier, T., Josserand, J., Ali, C., Vivien, D., Collingridge, G.L., Lombet, A., Issa, L., Rene, F., Loeffler, J.P., Kavelaars, A., Verney, C., Mantz, J., and Gressens, P. 2012. Activation of microglial N-methyl-D-aspartate receptors triggers inflammation and neuronal cell death in the developing and mature brain. Ann Neurol 72, 536-549, doi: 10.1002/ana.23626 Kakinuma, Y. 2020. Significance of vagus nerve function in terms of pathogenesis of psychosocial disorders. Neurochem Int 143, 104934, doi: 10.1016/j.neuint.2020.104934 Kato, G., Inada, H., Wake, H., Akiyoshi, R., Miyamoto, A., Eto, K., Ishikawa, T., Moorhouse, A.J., Strassman, A.M., and Nabekura, J. 2016. Microglial Contact Prevents Excess Depolarization and Rescues Neurons from Excitotoxicity. eNeuro 3, doi: 10.1523/ENEURO.0004-16.2016

Kershman, J. 1939. Genesis of microglia in the human brain. Arch. Neurol. Psychiatr. 41, 24-50, doi:

Kettenmann, H., Hanisch, U.K., Noda, M., and Verkhratsky, A. 2011. Physiology of microglia. Physiol Rev 91, 461-553, doi: 10.1152/physrev.00011.2010

Kettenmann, H., Kirchhoff, F., and Verkhratsky, A. 2013. Microglia: new roles for the synaptic stripper. Neuron 77, 10-18, doi: 10.1016/j.neuron.2012.12.023

Kikutani, K., Giga, H., Hosokawa, K., Shime, N., and Aizawa, H. 2020. Microglial translocator protein and stressor-related disorder. Neurochem Int 140, 104855, doi: 10.1016/j.neuint.2020.104855

Konishi, H., and Kiyama, H. 2020. Non-pathological roles of microglial TREM2/DAP12: TREM2/DAP12 regulates the physiological functions of microglia from development to aging. Neurochem Int 141, 104878, doi: 10.1016/j.neuint.2020.104878

Kuhn, S.A., van Landeghem, F.K., Zacharias, R., Farber, K., Rappert, A., Pavlovic, S., Hoffmann, A., Nolte, C., and Kettenmann, H. 2004. Microglia express GABA to modulate interleukin release. Mol Cell Neurosci 25, 312-322, doi:

Lam, T.I., Brennan-Minnella, A.M., Won, S.J., Shen, Y.G., Hefner, C., Shi, Y.J., Sun, D.D., and Swanson, R.A. 2013. Intracellular $\mathrm{pH}$ reduction prevents excitotoxic and ischemic neuronal death by inhibiting NADPH oxidase. Proc Natl Acad Sci U S A 110, E4362-E4368, doi: 10.1073/pnas.1313029110

Lauro, C., Di Angelantonio, S., Cipriani, R., Sobrero, F., Antonilli, L., Brusadin, V., Ragozzino, D., and Limatola, C. 2008. Activity of adenosine receptors type 1 Is required for CX3CL1-mediated neuroprotection and neuromodulation in hippocampal neurons. J Immunol 180, 7590-7596, doi: 10.4049/jimmunol.180.11.7590

Lin, S.S., Tang, Y., Illes, P., and Verkhratsky, A. 2020. The safeguarding microglia: central role for $\mathrm{P}_{2} \mathrm{Y}_{12}$ receptors. Front Cellular Neurosci, doi: 
Liu, Y., Kintner, D.B., Chanana, V., Algharabli, J., Chen, X., Gao, Y., Chen, J., Ferrazzano, P., Olson, J.K., and Sun, D. 2010. Activation of microglia depends on $\mathrm{Na}^{+} / \mathrm{H}^{+}$exchange-mediated $\mathrm{H}^{+}$homeostasis. J Neurosci 30, 15210-15220, doi: 10.1523/JNEUROSCI.3950-10.2010

Liu, Y.U., Ying, Y., Li, Y., Eyo, U.B., Chen, T., Zheng, J., Umpierre, A.D., Zhu, J., Bosco, D.B., Dong, H., and Wu, L.-J. 2019. Neuronal network activity controls microglial process surveillance in awake mice via norepinephrine signaling. Nature Neuroscience 22, 1771-1781, doi: 10.1038/s41593-019-0511-3

Luo, L., Song, S., Ezenwukwa, C.C., Jalali, S., Sun, B., and Sun, D. 2021. Ion channels and transporters in microglial function in physiology and brain diseases. Neurochem Int 142, 104925, doi: 10.1016/j.neuint.2020.104925

Mapplebeck, J.C., Beggs, S., and Salter, M.W. 2016. Sex differences in pain: a tale of two immune cells. Pain 157 Suppl 1, S2-6, doi: 10.1097/j.pain.0000000000000389 Mittelbronn, M., Dietz, K., Schluesener, H.J., and Meyermann, R. 2001. Local distribution of microglia in the normal adult human central nervous system differs by up to one order of magnitude. Acta Neuropathol 101, 249-255, doi: 10.1007/s004010000284 Miyanishi, K., Sato, A., Kihara, N., Utsunomiya, R., and Tanaka, J. 2021. Synaptic elimination by microglia and disturbed higher brain functions. Neurochem Int 142, 104901, doi: 10.1016/j.neuint.2020.104901

Mondo, E., Becker, S.C., Kautzman, A.G., Schifferer, M., Baer, C.E., Chen, J., Huang, E.J., Simons, M., and Schafer, D.P. 2020. A Developmental Analysis of Juxtavascular Microglia Dynamics and Interactions with the Vasculature. J Neurosci 40, 6503-6521, doi: 10.1523/JNEUROSCI.3006-19.2020

Monif, M., Reid, C.A., Powell, K.L., Smart, M.L., and Williams, D.A. 2009. The P2X 7 receptor drives microglial activation and proliferation: a trophic role for $\mathrm{P}_{2} \mathrm{X}_{7} \mathrm{R}$ pore. J Neurosci 29, 3781-3791, doi:

Nagano, T., Kawasaki, Y., Baba, A., Takemura, M., and Matsuda, T. 2004. Up-regulation of $\mathrm{Na}^{+}-\mathrm{Ca}^{2+}$ exchange activity by interferon-gamma in cultured rat microglia. $\mathrm{J}$

Neurochem 90, 784-791, doi: 10.1111/j.1471-4159.2004.02511.x

Nakanishi, H., Ni, J., Nonaka, S., and Hayashi, Y. 2021. Microglial circadian clock regulation of microglial structural complexity, dendritic spine density and inflammatory response. Neurochem Int 142, 104905, doi: 10.1016/j.neuint.2020.104905

Newell, E.W., Stanley, E.F., and Schlichter, L.C. 2007. Reversed $\mathrm{Na}^{+} / \mathrm{Ca}^{2+}$ exchange contributes to $\mathrm{Ca}^{2+}$ influx and respiratory burst in microglia. Channels (Austin) 1, 366376, doi: 10.4161/chan.5391

Nimmerjahn, A., Kirchhoff, F., and Helmchen, F. 2005. Resting microglial cells are highly dynamic surveillants of brain parenchyma in vivo. Science 308, 1314-1318, doi: $10.1126 /$ science. 1110647

Noda, M., Ifuku, M., Mori, Y., and Verkhratsky, A. 2013. Calcium Influx Through Reversed NCX Controls Migration of Microglia. Sodium Calcium Exchange: A Growing Spectrum of Pathophysiological Implications 961, 289-294, doi: 10.1007/978-1-46144756-6 24

Noda, M., Nakanishi, H., Nabekura, J., and Akaike, N. 2000. AMPA-kainate subtypes of glutamate receptor in rat cerebral microglia. J Neurosci 20, 251-258, doi:

Olson, J.K., and Miller, S.D. 2004. Microglia initiate central nervous system innate and adaptive immune responses through multiple TLRs. J Immunol 173, 3916-3924, doi: 
Paolicelli, R.C., Bolasco, G., Pagani, F., Maggi, L., Scianni, M., Panzanelli, P., Giustetto, M., Ferreira, T.A., Guiducci, E., Dumas, L., Ragozzino, D., and Gross, C.T. 2011.

Synaptic pruning by microglia is necessary for normal brain development. Science 333, 1456-1458, doi: 10.1126/science.1202529

Parkhurst, C.N., Yang, G., Ninan, I., Savas, J.N., Yates, J.R., 3rd, Lafaille, J.J., Hempstead, B.L., Littman, D.R., and Gan, W.B. 2013. Microglia promote learningdependent synapse formation through brain-derived neurotrophic factor. Cell 155, 15961609, doi: 10.1016/j.cell.2013.11.030

Parpura, V., Sekler, I., and Fern, R. 2016. Plasmalemmal and mitochondrial $\mathrm{Na}^{+}-\mathrm{Ca}^{2+}$ exchange in neuroglia. Glia 64, 1646-1654, doi: 10.1002/glia.22975

Piccinin, S., Di Angelantonio, S., Piccioni, A., Volpini, R., Cristalli, G., Fredholm, B.B., Limatola, C., Eusebi, F., and Ragozzino, D. 2010. CX3CL1-induced modulation at CA1 synapses reveals multiple mechanisms of EPSC modulation involving adenosine receptor subtypes. J Neuroimmunol 224, 85-92, doi: 10.1016/j.jneuroim.2010.05.012

Pocock, J.M., and Kettenmann, H. 2007. Neurotransmitter receptors on microglia. Trends Neurosci 30, 527-535, doi: 10.1016/j.tins.2007.07.007

Ragozzino, D., Di Angelantonio, S., Trettel, F., Bertollini, C., Maggi, L., Gross, C., Charo, I.F., Limatola, C., and Eusebi, F. 2006. Chemokine fractalkine/CX3CL1 negatively modulates active glutamatergic synapses in rat hippocampal neurons. J Neurosci 26, 10488-10498, doi: 10.1523/JNEUROSCI.3192-06.2006

Ribeiro Xavier, A.L., Kress, B.T., Goldman, S.A., Lacerda de Menezes, J.R., and Nedergaard, M. 2015. A Distinct Population of Microglia Supports Adult Neurogenesis in the Subventricular Zone. J Neurosci 35, 11848-11861, doi:

10.1523/JNEUROSCI.1217-15.2015

Rizzi, C., Tiberi, A., Giustizieri, M., Marrone, M.C., Gobbo, F., Carucci, N.M., Meli, G., Arisi, I., D'Onofrio, M., Marinelli, S., Capsoni, S., and Cattaneo, A. 2018. NGF steers microglia toward a neuroprotective phenotype. Glia 66, 1395-1416, doi:

10.1002/glia.23312

Rogers, J.T., Morganti, J.M., Bachstetter, A.D., Hudson, C.E., Peters, M.M., Grimmig, B.A., Weeber, E.J., Bickford, P.C., and Gemma, C. 2011. CX3CR1 deficiency leads to impairment of hippocampal cognitive function and synaptic plasticity. J Neurosci 31 , 16241-16250, doi: 10.1523/JNEUROSCI.3667-11.2011

Rose, C.R., and Verkhratsky, A. 2016. Principles of sodium homeostasis and sodium signalling in astroglia. Glia 64, 1611-1627, doi: 10.1002/glia.22964

Sakai, J. 2020. Core Concept: How synaptic pruning shapes neural wiring during development and, possibly, in disease. Proc Natl Acad Sci U S A 117, 16096-16099, doi: 10.1073/pnas.2010281117

Sanz, J.M., Chiozzi, P., Ferrari, D., Colaianna, M., Idzko, M., Falzoni, S., Fellin, R., Trabace, L., and Di Virgilio, F. 2009. Activation of microglia by amyloid $\beta$ requires $\mathrm{P}_{2} \mathrm{X}_{7}$ receptor expression. J Immunol 182, 4378-4385, doi:

Sasaki, Y., Hoshi, M., Akazawa, C., Nakamura, Y., Tsuzuki, H., Inoue, K., and Kohsaka, S. 2003. Selective expression of $\mathrm{G}_{\mathrm{i} / \mathrm{o}}$-coupled ATP receptor $\mathrm{P}_{2} \mathrm{Y}_{12}$ in microglia in rat brain. Glia 44, 242-250, doi: 10.1002/glia.10293

Savchenko, V.L., McKanna, J.A., Nikonenko, I.R., and Skibo, G.G. 2000. Microglia and astrocytes in the adult rat brain: comparative immunocytochemical analysis demonstrates 
the efficacy of lipocortin 1 immunoreactivity. Neuroscience 96, 195-203, doi:

10.1016/s0306-4522(99)00538-2

Schafer, D.P., Lehrman, E.K., Kautzman, A.G., Koyama, R., Mardinly, A.R., Yamasaki, R., Ransohoff, R.M., Greenberg, M.E., Barres, B.A., and Stevens, B. 2012. Microglia sculpt postnatal neural circuits in an activity and complement-dependent manner. Neuron 74, 691-705, doi: 10.1016/j.neuron.2012.03.026

Shi, Y.J., Kim, D., Caldwell, M., and Sun, D.D. 2013a. The Role of $\mathrm{Na}^{+} / \mathrm{H}^{+}$Exchanger Isoform 1 in Inflammatory Responses: Maintaining $\mathrm{H}^{+}$Homeostasis of Immune Cells. Adv Exp Med Biol 961, 411-418, doi: 10.1007/978-1-4614-4756-6_35

Shi, Y.J., Yuan, H., Kim, D., Chanana, V., Baba, A., Matsuda, T., Cengiz, P., Ferrazzano, P., and Sun, D.D. 2013b. Stimulation of $\mathrm{Na}^{+} / \mathrm{H}^{+}$Exchanger Isoform 1 Promotes

Microglial Migration. Plos One 8, doi: ARTN e74201

10.1371/journal.pone.0074201

Sierra, A., de Castro, F., Del Rio-Hortega, J., Rafael Iglesias-Rozas, J., Garrosa, M., and Kettenmann, H. 2016. The "Big-Bang" for modern glial biology: Translation and comments on Pio del Rio-Hortega 1919 series of papers on microglia. Glia 64, 18011840, doi: 10.1002 /glia.23046

Sierra, A., Encinas, J.M., Deudero, J.J., Chancey, J.H., Enikolopov, G., OverstreetWadiche, L.S., Tsirka, S.E., and Maletic-Savatic, M. 2010. Microglia shape adult hippocampal neurogenesis through apoptosis-coupled phagocytosis. Cell Stem Cell 7, 483-495, doi: 10.1016/j.stem.2010.08.014

Stratoulias, V., Venero, J.L., Tremblay, M.E., and Joseph, B. 2019. Microglial subtypes: diversity within the microglial community. EMBO J 38, e101997, doi:

10.15252/embj.2019101997

Stremmel, C., Schuchert, R., Wagner, F., Thaler, R., Weinberger, T., Pick, R., Mass, E., Ishikawa-Ankerhold, H.C., Margraf, A., Hutter, S., Vagnozzi, R., Klapproth, S., Frampton, J., Yona, S., Scheiermann, C., Molkentin, J.D., Jeschke, U., Moser, M., Sperandio, M., Massberg, S., Geissmann, F., and Schulz, C. 2018. Yolk sac macrophage progenitors traffic to the embryo during defined stages of development. Nature Communications 9, 75, doi: 10.1038/s41467-017-02492-2

Sugama, S., and Kakinuma, Y. 2020. Noradrenaline as a key neurotransmitter in modulating microglial activation in stress response. Neurochem Int 143, 104943, doi: 10.1016/j.neuint.2020.104943

Sunkaria, A., Bhardwaj, S., Halder, A., Yadav, A., and Sandhir, R. 2016. Migration and Phagocytic Ability of Activated Microglia During Post-natal Development is Mediated by Calcium-Dependent Purinergic Signalling. Mol Neurobiol 53, 944-954, doi: 10.1007/s12035-014-9064-3

Swinnen, N., Smolders, S., Avila, A., Notelaers, K., Paesen, R., Ameloot, M., Brone, B., Legendre, P., and Rigo, J.M. 2013. Complex invasion pattern of the cerebral cortex bymicroglial cells during development of the mouse embryo. Glia 61, 150-163, doi: 10.1002/glia.22421

Szalay, G., Martinecz, B., Lenart, N., Kornyei, Z., Orsolits, B., Judak, L., Csaszar, E., Fekete, R., West, B.L., Katona, G., Rozsa, B., and Denes, A. 2016. Microglia protect against brain injury and their selective elimination dysregulates neuronal network activity after stroke. Nat Commun 7, 11499, doi: 10.1038/ncomms11499 
Szepesi, Z., Manouchehrian, O., Bachiller, S., and Deierborg, T. 2018. Bidirectional Microglia-Neuron Communication in Health and Disease. Front Cell Neurosci 12, 323, doi: $10.3389 /$ fncel.2018.00323

Tay, T.L., Carrier, M., and Tremblay, M.E. 2019. Physiology of Microglia. Adv Exp Med Biol 1175, 129-148, doi: 10.1007/978-981-13-9913-8_6

Tay, T.L., Savage, J.C., Hui, C.W., Bisht, K., and Tremblay, M.E. 2017. Microglia across the lifespan: from origin to function in brain development, plasticity and cognition. $\mathrm{J}$ Physiol 595, 1929-1945, doi: 10.1113/JP272134

Timmerman, R., Burm, S.M., and Bajramovic, J.J. 2021. Tissue-specific features of microglial innate immune responses. Neurochem Int 142, 104924, doi:

10.1016/j.neuint.2020.104924

Toescu, E.C., Moller, T., Kettenmann, H., and Verkhratsky, A. 1998. Long-term activation of capacitative $\mathrm{Ca}^{2+}$ entry in mouse microglial cells. Neuroscience 86, 925-935, doi:

Tremblay, M.E., Lowery, R.L., and Majewska, A.K. 2010. Microglial interactions with synapses are modulated by visual experience. PLoS Biol 8, e1000527, doi:

10.1371/journal.pbio.1000527

Tremblay, M.E., Marker, D.F., Puccini, J.M., Muly, E.C., Lu, S.M., and Gelbard, H.A. 2013. Ultrastructure of microglia-synapse interactions in the HIV-1 Tat-injected murine central nervous system. Commun Integr Biol 6, e27670, doi: 10.4161/cib.27670

Tremblay, M.E., Stevens, B., Sierra, A., Wake, H., Bessis, A., and Nimmerjahn, A. 2011. The role of microglia in the healthy brain. J Neurosci 31, 16064-16069, doi: 10.1523/JNEUROSCI.4158-11.2011

Tsuda, M., Shigemoto-Mogami, Y., Koizumi, S., Mizokoshi, A., Kohsaka, S., Salter, M.W., and Inoue, K. 2003. P2X 4 receptors induced in spinal microglia gate tactile allodynia after nerve injury. Nature 424, 778-783, doi:

van Rossum, D., and Hanisch, U.K. 2004. Microglia. Metab Brain Dis 19, 393-411, doi: 10.1023/b:mebr.0000043984.73063.d8

Verkhratsky, A., and Burnstock, G. 2014. Biology of purinergic signalling: its ancient evolutionary roots, its omnipresence and its multiple functional significance. Bioessays 36, 697-705, doi: 10.1002/bies.201400024

Verkhratsky, A., Krishtal, O.A., and Burnstock, G. 2009. Purinoceptors on neuroglia. Mol Neurobiol 39, 190-208, doi: 10.1007/s12035-009-8063-2

Verkhratsky, A., Pankratov, Y., Lalo, U., and Nedergaard, M. 2012. P2X receptors in neuroglia. WIRES: Membrane Transport and Signaling 1, 151 - 161, doi:

Verkhratsky, A., Semyanov, A., and Zorec, R. 2020. Physiology of astroglial excitability. Function 1, zqaa016, doi: 10.1093/function/zqaa016 Wake, H., Moorhouse, A.J., Jinno, S., Kohsaka, S., and Nabekura, J. 2009. Resting microglia directly monitor the functional state of synapses in vivo and determine the fate of ischemic terminals. J Neurosci 29, 3974-3980, doi: 10.1523/JNEUROSCI.436308.2009

Wang, C., Yue, H., Hu, Z., Shen, Y., Ma, J., Li, J., Wang, X.D., Wang, L., Sun, B., Shi, P., Wang, L., and Gu, Y. 2020. Microglia mediate forgetting via complement-dependent synaptic elimination. Science 367, 688-694, doi: 10.1126/science.aaz2288

Weinhard, L., di Bartolomei, G., Bolasco, G., Machado, P., Schieber, N.L., Neniskyte, U., Exiga, M., Vadisiute, A., Raggioli, A., Schertel, A., Schwab, Y., and Gross, C.T. 2018. 
Microglia remodel synapses by presynaptic trogocytosis and spine head filopodia induction. Nat Commun 9, 1228, doi: 10.1038/s41467-018-03566-5

Wogram, E., Wendt, S., Matyash, M., Pivneva, T., Draguhn, A., and Kettenmann, H. 2016. Satellite microglia show spontaneous electrical activity that is uncorrelated with activity of the attached neuron. Eur J Neurosci 43, 1523-1534, doi: 10.1111/ejn.13256 Wolf, S.A., Boddeke, H.W., and Kettenmann, H. 2017. Microglia in Physiology and Disease. Annu Rev Physiol 79, 619-643, doi: 10.1146/annurev-physiol-022516-034406 Yamada, J., Sawada, M., and Nakanishi, H. 2006. Cell cycle-dependent regulation of kainate-induced inward currents in microglia. Biochem Biophys Res Commun 349, 913 919, doi: 10.1016/j.bbrc.2006.08.126

Zhan, Y., Paolicelli, R.C., Sforazzini, F., Weinhard, L., Bolasco, G., Pagani, F., Vyssotski, A.L., Bifone, A., Gozzi, A., Ragozzino, D., and Gross, C.T. 2014. Deficient neuron-microglia signaling results in impaired functional brain connectivity and social behavior. Nat Neurosci 17, 400-406, doi: 10.1038/nn.3641 


\section{Figure legends}

Figure 1. Phagocytic elimination of synapses by microglia.

Microglia in the frontal cortex (layer II) of normal 8-week-old Wistar rats actively phagocytose synaptophysin-positive synapses around at zeitgeber time 0 when sleeping period for rats starts. (a) Microglia appear to eliminate only synapses that are tagged with "eat-me-signals" such as a complement C3. (b) The phagocytosed synapses are present in the $\mathrm{CD} 68^{+}$phagosomes in the Iba1 ${ }^{+}$somata of microglia. 

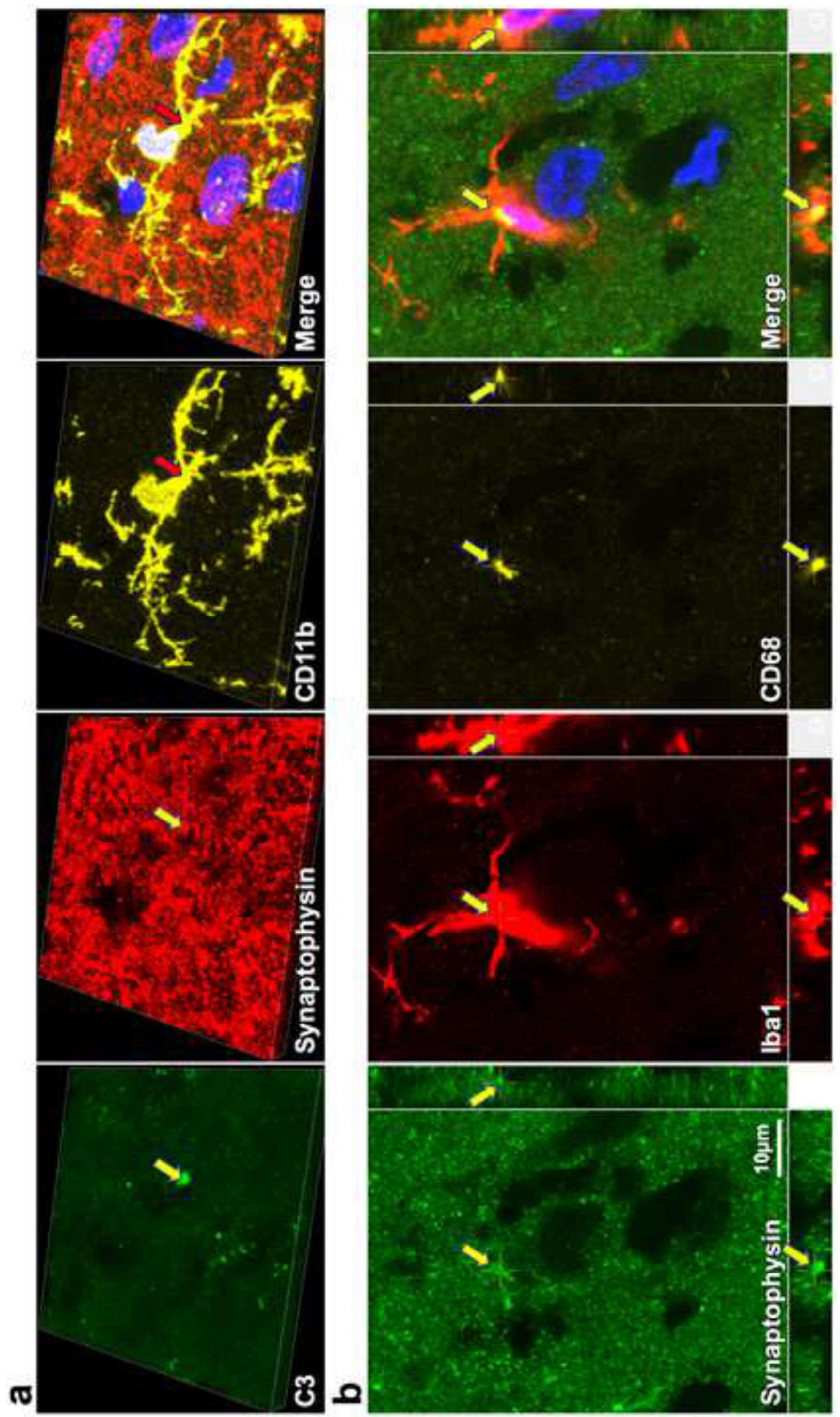

$\frac{\sigma}{\frac{0}{2}}$ 